\title{
ОСОБЕННОСТИ ЗАКОНОДАТЕЛЬСТВА ПО ЗАЩИТЕ ОТ НЕДОБРОСОВЕСТНОЙ КОНКУРЕНЦИИ В США
}

\section{FEATURES OF THE LEGISLATION ON PROTECTION AGAINST UNFAIR COMPETITION IN THE UNITED STATES \\ O. Kushka}

Summary: The Fight against unfair competition is a necessary condition for the stable functioning of the market economy. The United States is the country with the most developed system of legislation regarding protection against unfair competition. This article examines the regulation of Antimonopoly policy in this area, raises the problems of the legislative system, based on the analysis of the Federal structure of the state, using the legislative framework to combat unfair competition in the United States of America.

Keywords: unfair competition, US antitrust regulation, competition, trademarks, intellectual property.

\author{
Кушка Ольга Дмитриевна \\ РЭУ им. Плеханова, Москва \\ olgakushka@gmail.com
}

Аннотация: Борьба с недобросовестной конкуренцией является необходимым условием для стабильного функционирования рыночной экономики. США является страной с наиболее развитой системой законодательства В отношении защиты от недобросовестной конкуренции. В данной статье рассматривается регулирование антимонопольной политики в данной сфере, поднимается проблемы законодательной системы, опираясь на анализ федеративного устройства государства, с использованием законодательной базы по борьбе с недобросовестной конкуренцией в Соединенных Штатах Америки.

Ключевые слова: недобросовестная конкуренция, антимонопольное регулирование США, конкуренция, товарные знаки, интеллектуальная собственность.
B орьба с недобросовестной конкуренцией является необходимым условием для стабильного функционирования рыночной экономики. США является страной с наиболее развитой системой законодательства в отношении защиты от недобросовестной конкуренции. В данной статье рассматривается регулирование антимонопольной политики в данной сфере, поднимается проблемы законодательной системы, опираясь на анализ федеративного устройства государства, с использованием законодательной базы по борьбе с недобросовестной конкуренцией в Соединенных Штатах Америки. Целью данной статьи является проведение анализа и выявлению особенностей борьбы с недобросовестной конкуренции, с использованием информации в США, которые не рассмотрены в антимонопольном регулировании Российской Федерации.

Недобросовестная конкуренция возникает, когда другая компания использует неправильные или обманчивые методы ведения бизнеса для получения конкурентного преимущества. Основная категория недобросовестной конкуренции связана с намеренным введением потребителей в заблуждение относительно происхождения товара, в то время как второстепенная категория связана с недобросовестной торговой практикой. Некоторые из наиболее распространенных форм недобросовестной конкуренции в США включают в себя:

- Техника «продажи с наживкой», которая может быть реализована с помощью вводящей в заблуждение рекламы, публикации свидетельств о свойствах рекламируемой продукции, двойного этикетирования товаров, продажи продукции, отличающейся от рекламируемой, и продажи сверх рекламируемой цены.

- Ложная реклама или ложные заявления о продукте для его продвижения.

- Незаконное присвоение или использование конфиденциальной информации, например, кража специальной рецептуры конкурента или другой коммерческой тайны.

- Нарушение товарного вида или копирование внешнего вида продукта и / или упаковки в попытке обмануть клиента и заставить его купить.

- Нарушение прав на товарный знак.

- Нарушение определенных законодательным актов и норм, например положения о конкуренции.

- Ложное представление услуг или продуктов, например, преувеличение возможностей продукта.

- Искажение источника продукта, такая форма часто происходит, когда компания удаляет маркировку с продукта, а затем продает его.

- Несанкционированная замена одной марки товара или продукции на другую.

- Торговля клеветой или слухами, такими как письменные или устные сообщения, которые могут разрушить или повредить репутации компании в отрасли. 
- Имитация или подделка.

- Продажа ниже себестоимости.

Законы штата в основном регулируют недобросовестную конкуренцию, хотя вопросы нарушения прав на товарные знаки , ложной рекламы и авторских прав часто связаны с федеральными законами. Если проблема создает конфликт между законами штата и федеральными законами, федеральные законы, как правило, имеют приоритет перед законами штата.

Конгресс США учредил Федеральную торговую комиссию (The Federal Trade Commission) частично для защиты потребителей и других владельцев бизнеса от рисков недобросовестной конкуренции. Раздел 16 Кодекса федеральных правил содержит больше информации о конкретных мошеннических торговых практиках, которые могут нанести ущерб бизнесу и привести к путанице среди потребителей. Эта отрасль права интеллектуальной собственности, в частности, относится к практике замены товаров или услуг одной компании другой с целью введения потребителей в заблуждение.

В США существуют 4 основных способа «индивидуализации товаров юридических лиц или индивидуальных предпринимателей»:

1. Торговые названия: используется для идентификации названия партнерства, корпорации, индивидуального предпринимателя или другого субъекта предпринимательской деятельности. Компания может зарегистрировать торговое наименование в правительстве и действовать под этим именем, или это может быть условное название, под которым компания известна общественности. Одним из примеров является ресторан, известный как «Бар и Гриль Джона и Харриет» среди местных жителей, но зарегистрированный под названием «Бостон Корнер Таверна». В этом случае оба названия будут считаться торговыми наименованиями в рамках законов о недобросовестной конкуренции США.

2. Торговые марки (товарный знак): слова, символы, фразы, слоганы, эмблемы и другие устройства, используемые для обозначения подлинности и источника для общественности. Когда компания использует зарегистрированный товарный знак, клиент может легко идентифицировать продукт и поддерживать лояльность к бренду.

3. Знаки обслуживания: аналогично товарным знакам, но для услуг вместо товаров. Например, Orkin Pest Control предоставляет услуги по борьбе с вредителями, поэтому защита компании зарегистрирована как знак обслуживания.

4. Товарный вид: внешний вид продукта или способ его представления, упаковки, упаковки или продвижения могут все подпадать под товарный знак. Товарный вид также может включать форму, дизайн, форму и / или текстуру конкретного продукта или упаковки. Даже определенные цветовые комбинации могут служить фирменным стилем компании, такие как красно-желтая цветовая схема, используемая Chevron Chemical Company.

Защиту от недобросовестной конкуренции в данной сфере применяется только в случае, если эти четыре основных устройства должны быть отличительными. Использование общих фраз или слов может ограничить конкуренцию, поэтому они не имеют права на защиту торговой марки.

Эти устройства считаются нематериальными активами для бизнеса, наряду с его творческими работами, изобретениями и технологиями. Дополнительные нематериальные активы считаются коммерческими секретами, которые могут включать процессы, формулы, шаблоны, методики, программы, механизмы, соединения или инструменты, которые дают компании возможность получить преимущество перед конкурентами. Торговые секреты не могут быть защищены авторским правом или запатентованы, поэтому они, как правило, передаются только избранной группе людей, которые будут хранить их в тайне.

Владелец коммерческой тайны может исключительно использовать и извлекать выгоду из информации. Закон о недобросовестной конкуренции позволяет защищать коммерческую тайну разумными мерами. С другой стороны, коммерческая информация, которой обмениваются с общественностью, практически не имеет коммерческой ценности. Кража коммерческой тайны может привести к тому, что лица, разглашающие информацию, будут нести ответственность за ущерб и экономический ущерб. Сотрудник или бывший сотрудник также может быть привлечен к ответственности за передачу коммерческой тайны.

Законы об авторском праве и патентах могут защищать информацию, предоставляемую общественности, при условии, что информация защищена в соответствии с этими законами. Чтобы претендовать на патент или защиту авторских прав, вы должны подать заявки в соответствующие государственные органы. Законы об авторском праве США [4] защищают оригинальные произведения, такие как драматические произведения, фильмы, звукозаписи, пантомимы, музыкальные партитуры и книги. Патентные законы защищают изобретения, такие как химические формулы, производственные процессы, механические устройства и электрооборудование.

К основным законом, регулирующим недобросовест- 
ную конкуренции, относятся следующие антимонопольные нормативно-правовые акты:

- Закон Шермана (1890 г.)

- Законом Клейтона (1914 г.)

- Закон Робинсона-Пэтмана (1936 г.)

В настоящее время в США появилось несколько новых аспектов в недобросовестной конкуренции, которые требуют законодательных актов. Данные понятия, которые будут рассмотрены ниже, характерны для законодательной системы США. В Соединенных Штатах Америки помимо антимонопольных актов о недобросовестной конкуренции в отношении информации, действуют дополнительные законодательные аспекты. Проведя анализ, мы выделили самые актуальные на сегодняшний момент:

- Доктрина первой продажи (The Exhaustion Doctrine)

Доктрина рассматривает вопросы распространения продуктов, защищенных авторским правом, прокат видео, вторичный рынок для произведений, охраняемых авторским правом (например, возможность продавать окружающим легально приобретенные книги или компакт-диски). Для товарных знаков эта доктрина позволяет перепродавать торговые марки продуктов после того, как владелец товарного знака выложит эти продукты на рынке. Эту доктрину также называют «правом первой продажи», «правилом первой продажи» или «правилом исчерпания.» [4]

- Подразумеваемый Обратный Пассинг (Implied Reverse Passing Off)

Для данного аспекта точного российского перевода термина не предназначено. В России его можно отнести к более широкому понятию введению в заблуждение в отношении производителя товара (п. 2 ч. 1 ст. 14 Ф3 «О защите конкуренции»). Impliend Reverse Passing Off происходит, когда компания или частное лицо удаляет марку с продукта для продажи, пытаясь выдать продукт за другой. Суды признают это требование согласно разделу 43 (а) законов о недобросовестной конкуренции. Если федерально зарегистрированный знак будет удален, это может ввести в заблуждение конечных потребителей. Также данный момент закреплен в Законе Ланхэма (действующая редакция с последними изменениями 1988г.). [6]

- Выраженный Обратный Пассинг (Express Reverse Passing Off)

Данный аспект представляет собой ситуацию, когда компания или частное лицо удаляет отметку на товаре или услуге, а затем переименовывает товар, чтобы выдать его за свой собственный. Это нарушает раздел 43 (а), как и Подразумеваемый Обратный Пассинг. Но в данном случае Возбуж- дение судебного иска против явной обратного пассинга может быть сложной задачей, поскольку суды не всегда применяют согласованные правила и руководящие принципы с точки зрения того, что нарушает закон. В судебной практике США решения принимаются индивидуально в отношении каждого случая, по делу Выраженного Обратного Пассинга.

- Преобразование в новый продукт (Conversion into a New Product (Altering the File))

Данный аспект является обратным для двух предыдущих понятий. Если компания или частное лицо может доказать, что модификаций и изменений исходного продукта было достаточно, чтобы не ввести в заблуждение потребителя - то дело по недобросовестной конкуренции не возбуждается.

Стоит отметить, что аспекты по Оборотным Пассингам, а также различиям их от Преобразованием в новый продукт, в российском законодательстве не рассмотрены. Как было отмечено выше, даже на территории США данные аспекты представляют трудность для принятия однозначных решений в судебной практике.

Таким образом, если мы рассматриваем недобросовестную конкуренции в сфере информации в США, помимо антимонопольных законов, которые защищают конкуренцию, важную роль играет Закон Ланхэма. Именно этот закон о товарных знаках защищает государство на территории всех штатов от так называемой «паразитической конкуренции». Также стоит отметить, что федеративное устройство США предполагает, что помимо положений федеральных законов, существуют законы штатов, которые могут различаться между собой и предполагать различные меры защиты и ответственности. После анализа нескольких штатных законодательных актов по недобросовестной конкуренции с использованием информации, мы сделали вывод, что основой для большинства служит Единообразный закон об обманной торговой практике [7], принятый в 1964 году. Также стоит отметить, что право США основывается прежде всего на судебных прецедентах. Как отмечает В.И. Еременко: «Законы рассматриваются здесь как дополнение к совокупности норм, установленных судебной практикой, а их полноправное вхождение в состав законодательства происходит, по сути дела, после их применения и толкования судами» [12, с. 79]. Таким образом, мы приходим к выводу, что несмотря на законы штатов в сфере защиты от недобросовестной конкуренции, решающая роль принадлежит совокупности судебных решений, устанавливающих прецедент. Антимонопольное законодательство в отношении недобросовестной конкуренции ежегодно меняется, но по средствам судебного решения, а не изменений определенного законодательного акта. 
1. Акт Шермана (Sherman Act 1890)

2. Закон Клейтона (Clayton Antitrust Act 1914)

3. Закон Робинса-Пэтмана (Robinson Patman Act 1936)

4. Закон США об авторском праве предоставляет монопольную защиту «оригинальным авторским произведениям» из 17 Кодекса США § 102.

5. Закон $о б$ авторском праве 1976, 17 U. S. С. § 109

6. Закон Ланхэма (1946) редакция с изменениями от 1988 года.

7. Единообразный торговый кодекс (ША The Uniform Commercial Code (1964 г.)

8. Довгалюк А. публикация от 28.04.2015 «Reverse Passing Off в России» \Доступ: https://zakon.ru/discussion/2015/04/28/prodaesh_chuzhoj_tovar_kak_ svoj_i_normalno__reverse_passing_off_v_rossii

9. Пугинский Б.И., Амиров А.Т. Важный шаг в развитии торгового законодательства США // Коммерческое право. — 2008. — № 1 (2).

10. Ласк Г. Гражданское право США (право торгового оборота). — М., 1961.

11. Гражданское и торговое право зарубежных государств / Отв. ред. Е. А. Васильев, А. С. Комаров. — 4-е изд. - М., 2004. - Т. I.

12. Еременко В.И. Законодательство о пресечении недобросовестной конкуренцией капиталистических стран. — М., 1991. — С.79.

13. Электронный ресурс: Legal Information Institute \ Доступ: https://www.law.cornell.edu/

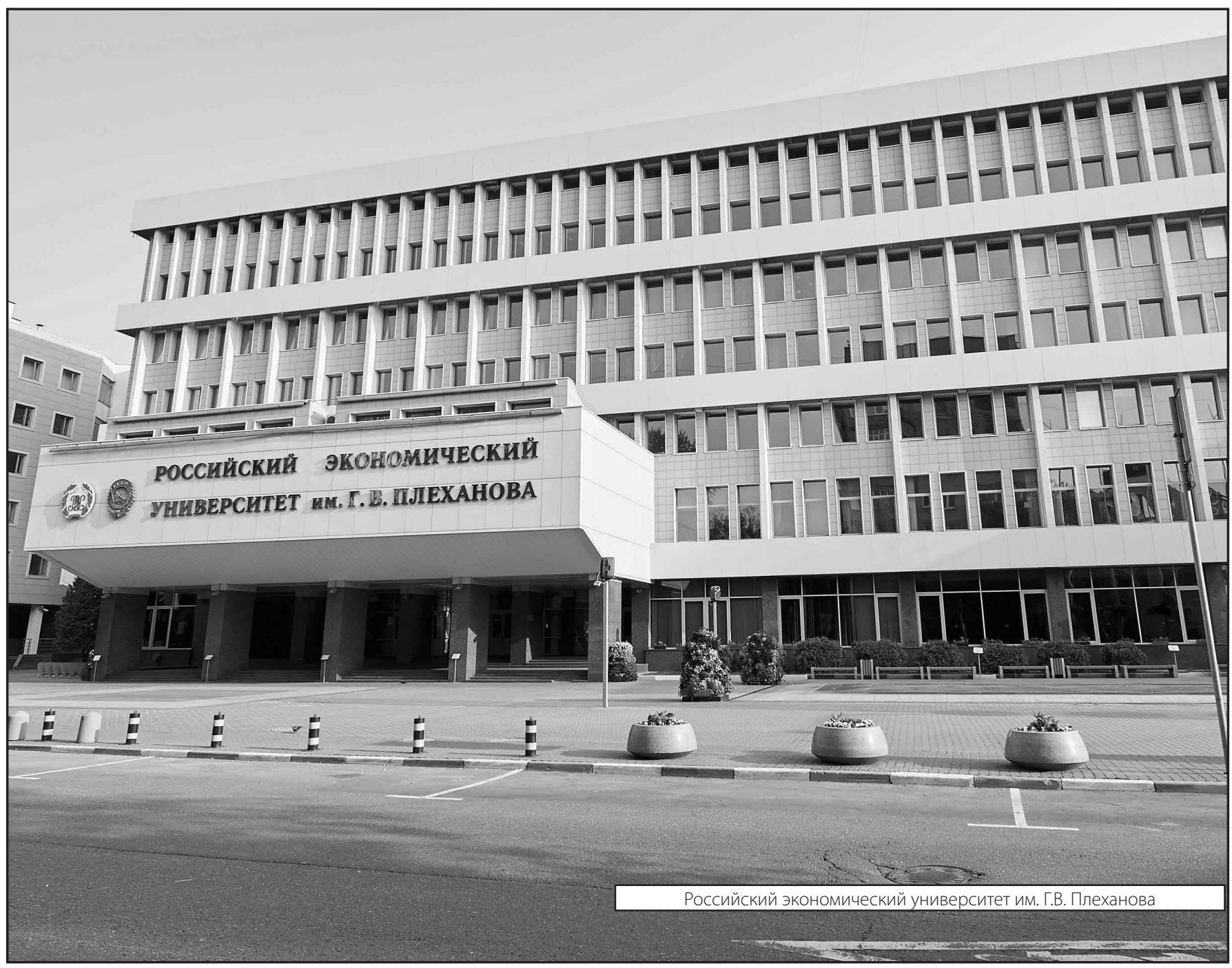

